\title{
More Diversity? Talk is Cheap
}

\section{Noah Carl}

In a paper dealing with the apparent inconsistency of professing egalitarian beliefs while enjoying a well-above average income, G. A. Cohen asked, "If you're an egalitarian, how come you're so rich?"1 This paper asks a similar question of academics who are members of overrepresented groups and purport to be in favor of more "diversity"; specifically, if you're in favor of more “diversity,” how come you haven’t resigned?

Women and some ethnic minorities are underrepresented in academia, especially in senior positions at elite colleges. ${ }^{2}$ For example, in the United States in 2018, white men comprised only 33 percent of the civilian labor force, but made up 40 percent of college faculty and 53 percent of professors. Likewise, Asian men comprised only 3 percent of the civilian labor force, but made up 6 percent of college faculty and 8 percent of professors. By contrast, black women comprised 6 percent of the civilian labor force, but made up only 3 percent of college faculty and only 2 percent of professors. Likewise, Hispanic women comprised 8 percent of the civilian labor force, but made up only 3 percent of college faculty and only 1 percent of professors. ${ }^{3}$

Many academics who are members of overrepresented groups have indicated that they want to increase the representation of women and ethnic minorities. ${ }^{4}$ However, since any academic from an overrepresented group

1 G. A. Cohen, "If You're an Egalitarian, How Come You're so Rich?," Journal of Ethics 4, no. 1-2 (2000): 1-26.

2 Martin Finkelstein, Valerie Martin Conley, and Jack H. Schuster, Taking the Measure of Faculty Diversity (New York City, NY, 2016).

3 "Professor" here refers to those with "Full Professor" status, while faculty includes Associate Professor, Assistant Professor, Instructor, Lecturer or Other faculty. U.S. Bureau of Labor Statistics, "Labor Force Characteristics by Race and Ethnicity, 2018," 2019; National Center for Education Statistics, 2020, "Characteristics of Postsecondary Faculty," https://nces.ed.gov/programs/coe/indicator_csc. asp\#info.

4 The word "diversity" is placed in quotation marks throughout this paper, due to the fact that its meaning in the present context is contested. 
who remains in his position is directly contributing to the lack of "diversity," it is argued that such academics have an obligation to resign and give up their positions to members of underrepresented groups. The paper takes no position on whether it is desirable to increase "diversity."

\section{Support for Increasing “Diversity”}

First, two recent studies found that male academics prefer to hire female candidates, and white academics prefer to hire non-white candidates. Ceci and Williams sent out trios of application materials to a large, national sample of U.S. college faculty in math-intensive fields. ${ }^{5}$ Each trio of application materials comprised two male candidates and one female candidate. The second male candidate, who was described as slightly less qualified, was included as a foil. The other two candidates were evenly matched for credentials (departmental evaluations, reference letters etc.). Respondents were asked to rank the three candidates in order of preference. On average, male respondents in biology, engineering, and psychology rated the female candidate as more hireable than the equally qualified male candidate about two-thirds of the time. (Male respondents in economics rated the female candidate as more hireable slightly less than 50 percent of the time, although the difference was not statistically significant.)

Carey et al. asked a large sample of faculty at the University of New Mexico and the University of Nevada, Reno to participate in a survey experiment on faculty recruitment. ${ }^{6}$ Each respondent was shown pairs of profiles corresponding to candidates with different characteristics (gender, race, teaching record etc.). These characteristics were randomly selected from a predetermined set. Respondents were asked to say, for each pair of profiles, which candidate they would prefer to be hired at their university. (The research design used by Carey et al. is known as conjoint analysis.) On average, white respondents showed a strong preference for non-white candidates, and male

5 Wendy M. Williams, Stephen J. Ceci, "National Hiring Experiments Reveal 2:1 Faculty Preference for Women on STEM Tenure Track," Proceedings of the National Academy of Sciences of the United States of America 112, no. 17 (2015): 5360-65.

6 John M. Carey et al., "Who Wants to Hire a More Diverse Faculty? A Conjoint Analysis of Faculty and Student Preferences for Gender and Racial/Ethnic Diversity," Politics, Groups, and Identities (2018):1-19. 
respondents showed a small-to-moderate preference for female candidates. This was true at both universities in the study. ${ }^{7}$

Second, many academics who are members of overrepresented groups have signed petitions criticising other academics who have questioned, or who have been interpreted as questioning, the putative benefits of faculty "diversity." In June of 2019, the editor of Rhetoric and Public Affairs, Professor Martin Medhurst, sent out an email to some members of the National Communication Association (a scholarly society for the discipline of communications) containing a draft editorial that he had intended to publish in Rhetoric and Public Affairs. The editorial's purpose was to argue against some proposed changes to the way the NCA's Distinguish Scholar Awards would be selected. In response to Medhurst's email, more than 1,300 students and academics signed an open letter that denounced him for seeking to "undermine the work of a diverse group of NCA leaders." The signatories, who described themselves as "scholars of color, members of other marginalized groups, and allies," stated, "We are united in our conviction that any acceptable response to the current exigence must entail a public and emphatic re-commitment to our discipline's espoused goals of diversity and social justice." Perusal of the list of signatories reveals the presence of many individuals who are members of overrepresented groups.

In December of 2019, Professor Abigail Thompson (a vice president of the American Mathematical Society) penned an opinion piece for Notices of the American Mathematical Society which argued against the use of mandatory “diversity statements” in faculty hiring. ${ }^{9}$ Her piece prompted a number of responses, including one open letter that criticised Thompson signed by over 600 students and academics. This letter noted, “We are writing because we support diversity statements as one tool to encourage a more inclusive and equitable mathematics profession" and was titled "The math community values a commitment to diversity." The letter's signatories were 49 percent male and 72 percent white; a further 7 percent were Asian. ${ }^{10}$

$7 \quad$ Male respondents' preference for female candidates was significant at the University of New Mexico but not at the University of Nevada, Reno.

8 Bernadette Marie Calafell, "An Open Letter on Diversity in the Communication Discipline," Bernadette Calafell Ph.D, 2019, https://web.archive.org/web/20191127073323/http://bernadettemariecalafellphd.com/?page_id=847.

9 Abigail Thompson, "A Word from. ... Abigail Thompson," Notices of the American Mathematical Society 66, no. 11 (2019): 1778-79.

10 Erica Flapan, 'Responses to "A Word From... Abigail Thompson"', Notices of the American Mathematical Society Online (2019): 1-25; Chad M. Topaz et al., "Comparing Demographics of Signatories to Public Letters on Diversity in the Mathematical Sciences," PLoS ONE 15, no. 4 (2020). 
Third, leading academic journals have run editorials emphasizing the need for more "diversity." Nature, which is considered one of the world's most prestigious scientific journals, has run a number of such editorials over the last few years. ${ }^{11}$ For example, in June of 2018, it ran an editorial titled "Science benefits from diversity." In May of 2019, it ran an editorial titled "Improving diversity in the physical sciences needs more than data-it needs resolve, too." And in July of 2019, it ran an editorial titled "Diversity and international collaboration should not become casualties of anti-espionage policies." Perusal of Nature's editorial board reveals the presence of several individuals who are members of overrepresented groups. Other journals that have run editorials emphasising the need for more "diversity” include Nature Reviews Genetics, Nature Astronomy, and Cell..$^{2}$

Fourth, individual academics who are members of overrepresented groups have written articles emphasizing the need for more "diversity." One such individual penned an article titled "Why science needs more diversity," in which he referred to the "problem of making our scientific community more diverse."13 Another such individual penned an article titled "Why I'm not applying for promotion," in which he stated the following:

If scientists want genuine, rapid change, we must implement actions to address this diversity crisis. One such action is for male academics to delay their senior promotion until bias in their department or at their institution has been reduced and salary gaps have been "balanced," or they see some other indicator of parity. ${ }^{14}$

The author went on to note that some universities "have implemented female-only appointment strategies and positions" and that one university even advertised three mid-career positions "for female applicants only." $\mathrm{He}$ concluded the article as follows: "I am a white male tenured scientist, and I believe that I have a greater responsibility than most.”

11 Editorial, "Science Benefits from Diversity," Nature 558 (2018): 5-5; Editorial, "Improving Diversity in the Physical Sciences Needs More than Data-It Needs Resolve, Too," Nature 569 (2019): 159-159; Editorial, "Diversity and International Collaboration Should Not Become Casualties of Anti-Espionage Policies," Nature 571 (2019): 297-297.

12 Editorial, "Diversity Matters," Nature Reviews Genetics 20 (2019): 495-495; Editorial, "Actions Speak Louder than Words," Nature Astronomy 3 (2019): 1031-1031; Cell Press, "Science Has a Racism Problem: Cell," accessed June 8, 2020, http://info.cell.com/s0092-86742030740-6.

13 Michael White, "Why Science Needs More Diversity," Pacific Standard, accessed June 1, 2020, https://psmag.com/education/why-science-needs-more-diversity.

14 Phil Cassey, "Why I'm Not Applying for Promotion," Nature, November 11, 2019. 


\section{The Obligation to Resign}

Merely delaying one's promotion is insufficient. Academics from overrepresented groups who are in favor of more "diversity" have an obligation to resign and give up their positions to members of underrepresented groups. The fundamental reason they have this obligation is that "diversity" concerns the extent to which the demographic composition of academia matches the demographic composition of the general population. An institution that currently lacks "diversity" will be considered more "diverse" if the percentage of individuals from underrepresented groups goes up. However, the percentage of individuals from underrepresented groups cannot go up unless the percentage of individuals from overrepresented groups goes down. Hence any individual from an overrepresented group who remains in his position is directly contributing to the lack of "diversity." As Thomas Schelling noted, "If your problem is that there is too much traffic, you are part of the problem." ${ }^{15}$

There are several reasons why an individual from an overrepresented group who is in favor of more "diversity" might decide to remain in his position. First, his professed beliefs, or the beliefs he has conveyed through his responses in survey experiments, might not be his actual beliefs. He might, in other words, be lying. ${ }^{16}$ Such an individual would therefore be morally blameworthy unless there were extenuating circumstances. What possible extenuating circumstances could there be? One might argue that the individual had a reasonable concern that if he did not express support for more "diversity," his career prospects would be harmed. Such a concern would not be totally misplaced, given what happened to Professor Martin Medhurst and Professor Abigail Thompson. However, there is a difference between not expressing support for a cause and expressing opposition to that cause, and it would be difficult to maintain that the potential harm to one's career from merely not expressing support for more "diversity” justified lying about one's beliefs. ${ }^{17}$ In addition, stating that you're not actually in favor of more "diversity" is obviously not a principled objection to the claim that you have an obligation to resign if you purport to be in favor of more "diversity."

15 Thomas C. Schelling, Micromotives and Macrobehavior (Norton, 1978).

16 Philosophers disagree about the definition of "lying." At the very least, it can be said that the individual is intentionally conveying false information.

17 One reason it would be difficult to justify lying is that doing so could impose costs on third-parties. For example, it might lead to academics from over-represented groups losing job opportunities. 
Second, he may believe that, by expressing support for more "diversity," he is merely advocating meritocracy, and since he attained his own position meritocratically, he is under no obligation to give it up to someone from an underrepresented group. He is merely saying, in other words, that he wants the most qualified candidates to be hired, and he expects that this will result in an increase in the representation of women and ethnic minorities. However, if “diversity” were synonymous with “meritocracy," there would be no need for the term in the first place. Moreover, "diversity” has no prior semantic connection with "meritocracy" and does not appear to be treated as synonymous with "meritocracy" in the public debate. ${ }^{18}$ As noted above, "diversity" concerns the extent to which the demographic composition of academia matches the demographic composition of the general population. For example, Harvard has been accused of having an unmeritocratic admissions process because it takes into account factors other than test scores and high school grades, and its stated reason for doing so is to ensure there is sufficient "diversity" on campus. ${ }^{19}$ In this case, "diversity" and meritocracy are arguably opposed. If an individual who expresses support for more "diversity” does so while admitting that "diversity" and meritocracy are not synonymous, then the arguments in the preceding paragraph may apply to him. If he does so while affirming that they are synonymous, then he is engaged in an error.

Third, he may contend that an increase in faculty "diversity” can be achieved without any decrease in the number of individuals from overrepresented groups, meaning that there is no need for anyone to resign. Specifically, a large number of new positions could be created, and they could all be allocated to individuals from underrepresented groups. This would result in an immediate increase in the percentage of individuals from underrepresented groups, and a corresponding decrease in the percentage of individuals from overrepresented groups. However, given that the demand for academics is relatively stable from year to year, and universities' resources are limited, it is highly implausible that a large number of new positions will be created any time soon in the face of birth rate declines and a global pandemic. Hence, although it is theoretically

18 Heather MacDonald, The Diversity Delusion: How Race and Gender Pandering Corrupt the University and Undermine Our Culture (St. Martin's Publishing Group, 2018); Jordan Peterson, "The Great Ideological Lie of Diversity," Jordan Peterson, November 2019.

19 "The Model Minority Is Losing Patience," The Economist, accessed June 2, 2020, https://www. economist.com/briefing/2015/10/03/the-model-minority-is-losing-patience; Heather MacDonald, "Harvard Admits Its Preferences," accessed June 2, 2020, https://newcriterion.com/issues/2019/11/ harvard-admits-its-preferences. 
possible to increase "diversity" by expanding the number of academic positions, there is no reason to believe that the number of positions will be expanded in the relatively near future. Until such time as the number of positions is expanded, any individual from an overrepresented group who advocates more "diversity" remains obligated to resign.

Fourth, he may believe that although increasing "diversity" is important, his personal employment situation is more important. He may believe, in other words, that increasing "diversity" matters, but does not matter enough for him to make a material contribution by giving up his position. This reasoning is unsatisfactory because it patently flouts the categorical imperative. ${ }^{20}$ If everyone acted according to this reasoning, then "diversity" could only ever increase via the gradual replacement of less "diverse" cohorts by more "diverse" cohorts. Moreover, why should academics from overrepresented groups who do not have faculty positions have to pay all the costs associated with increasing “diversity"? Incumbents from overrepresented groups have already enjoyed the benefits of having a faculty position for some amount of time. And any bias in favor of academics from overrepresented groups was arguably greater in the past than it is now, meaning that incumbents have less grounds for saying that they were selected meritocratically. In addition, paying lip service to the importance of "diversity" without ever making a material contribution risks undermining the movement by causing it to become associated with hypocrisy. ${ }^{21}$

Fifth, the pro-“diversity" academic may insist that there is no way of ensuring that his position would go to someone from an underrepresented group. Alternatively, he may insist that his specific knowledge and skills are vital to the running of his institution, or that his particular research projects confer massive benefits on the wider society. However, all these objections could be readily accommodated. There could be a mentoring period in which both the incumbent and his replacement were employed by the university, and the former instructed the latter on how to carry out his teaching, research, and administrative duties. At the end of this period, the incumbent would resign, and the replacement would take up the new role. ${ }^{22}$

20 Immanuel Kant, Kant: Groundwork of the Metaphysics of Morals, ed. Mary Gregor, Cambridge Texts in the History of Philosophy (Cambridge: Cambridge University Press, 1998).

21 Jillian J. Jordan et al., "Why Do We Hate Hypocrites? Evidence for a Theory of False Signaling," Psychological Science 28, no. 3 (March 1, 2017): 356-68.

22 The literature on racial reparations offers a precedent for asking individuals to make a contribution to transitional justice based on collective, rather than individual, responsibility. See Charles P. Henry, "The Politics of Racial Reparations," Journal of Black Studies 34, no. 2 (2003): 131-52. 


\section{Conclusion}

Any academic from an overrepresented group who advocates more "diversity" is directly contributing to the lack of "diversity" by remaining in his position. Assuming the number of jobs is relatively fixed, such an individual is effectively saying, "I want the percentage of academics who have the same demographic characteristics as me to go down, but I am not willing to give up my job in order to achieve that goal. Rather, I want other academics with those demographic characteristics to give up their jobs, or to lose job opportunities.” Needless to say, this is not a principled stance. Academics from overrepresented groups who are in favor of more "diversity" have an obligation to resign, and they should continue to fulfil this obligation until the demographic composition of academia matches the demographic composition of the general population. 